\title{
ON TWO NEW SPECIES OF THE TREMATODE GENERA, OPISTHIOPARORCHIS WANG, 1980 AND BATRACHOTREMA DOLLFUS AND WILLIAMS, 1966 (BATRACHOTREMATIDAE), WITH A REPORT OF A CHINESE SPECIES OF OPISTHIOPARORCHIS FROM ANURAN AMPHIBIAN HOSTS IN INDIA
}

\author{
Veena Tandon ${ }^{1}$, R. Imkongwapang ${ }^{2}$ and Pramod Kumar Prasad ${ }^{3}$ \\ 1,3 Department of Zoology, North-Eastern Hill University, Shillong, Meghalaya 793022, India \\ ${ }^{2}$ Department of Zoology, Nagaland University, Mokokchung, Nagaland, India \\ Email: ${ }^{1}$ tandonveena@hotmail.com
}

web supplement

\begin{abstract}
An examination of small samples of three species of anuran frogs (Amolops afghanus, Rana liebigii and R. khare) originating in Nagaland (northeastern India) revealed three species of trematodes, two of them being new to science. These include Batrachotrema nagalandensis sp. nov. (type host A. afghanus), Opisthioparorchis indica sp. nov. (type host A. afghanus) and O. yunnanse $L i$, 1996. This is the first record of their respective genera in India. The distinguishing features of B. nagalandensis sp. nov. are - testes located in the middle third of the body, and long cirrus sac extending posteriorly beyond the ventral sucker. O. indica sp. nov. is distinguished by having oral and ventral suckers of almost equal size, intestinal caeca extending beyond the ventral sucker up to the anterior border of testes, the genital pore at the level of the oral sucker and vitellaria confluencing medially in the pre and post testicular regions. Kohima (Nagaland) and Rana liebigii form a new locality and new host record, respectively, for $\mathrm{O}$. yunnanse.
\end{abstract}

\section{KeYWORDS}

Amolops afghanus, Batrachotrema nagalandensis sp. nov., India, Nagaland, Opisthioparorchis indica sp. nov., Opisthioparorchis yunnanse, Rana khare, Rana liebigii, Trematode

During an exploratory survey of the helminth parasite fauna of anuran Amphibia in Nagaland (India) several digenetic trematode species were encountered. Two of these forms, on study, were found to be new to science and belong each to the genera Batrachotrema Dollfus and Williams, 1966 and Opisthioparorchis Wang, 1980. While the former genus has hitherto been reported from Africa (Dollfus \& Williams, 1966), China (Wang, 1981; Zhang \& Sha, 1985; Liang \& Ke, 1988) and Vietnam (Moravec \& Sey, 1989) the latter is represented so far in ranid frogs in China. The present communication deals with the description of a new species of each genus, and also forms the first record of the occurrence of these genera in the Indian subcontinent. The occurrence of $O$. yunnanse Li, 1996 is also reported from Rana liebigii as a new record.

\section{Materials And Methods}

Eight specimens (range 1-4) of Batrachotrema were collected from the intestine of five A. afghanus and only one specimen, from Rana khare at Mokokchung in Nagaland. Twenty-one specimens of a form belonging to Opisthioparorchis were recovered from the intestine of three Amolops afghanus from Mokokchung, the maximum number of this parasite in a single host being 18. Two specimens, also belonging to the same genus but representing another species were collected from one Rana liebigii from Kohima.

Whole mount preparations of the flukes were made following standard procedure, using Mayer's carmalum or borax carmine as stains. For scanning electron microscopy (SEM) the specimens fixed in $4 \%$ cold neutral buffered formalin were processed and treated with tetramethylsilane as per the method described by Roy and Tandon (1991), metal coated and viewed under a JSM-35 CF (Jeol) scanning electron microscope at accelerating electron voltage ranging between $10-15 \mathrm{kV}$.

Family Batrachotrematidae

Genus Batrachotrema Dollfus and Williams, 1966

Batrachotrema nagalandensis sp. nov.

(Figs. 1-3; Images 1-2 ${ }^{\mathrm{w}}$ )

\section{Material examined}

Holotype: W 8338/1; from the intestine of Amolops afghanus (Günther), Mokokchung, Nagaland $\left(25^{\circ}-27^{\circ} 4^{\prime} \mathrm{N} \& 93^{\circ} 2^{\prime}-95^{\circ} 15^{\prime} \mathrm{E}\right)$. Paratypes: W 8339/1, W 8340/1; from the intestine of Amolops afghanus (Günther) and Rana khare (Kiyasetuo \& Khare), Mokokchung.

Deposited at the Zoological Survey of India, Kolkata.

\section{Etymology \\ Named after Nagaland state, India.}

Specific diagnosis

Body unspined, fusiform, testes located in middle third of body; cirrus sac long, extending beyond ventral sucker posteriorly, ovary rounded.

\section{Diagnosis}

(Based on measurements of 5 mature specimens and SEM observations on 1 specimen.). Body elongated or some what spindle shaped, broadest at shoulder, tapering and terminating bluntly towards anterior and posterior regions; surface devoid of spines. Oral sucker subterminal. Ventral sucker pre-

${ }^{w}$ Also see SEM Images in the web supplement at www.zoosprint.org 


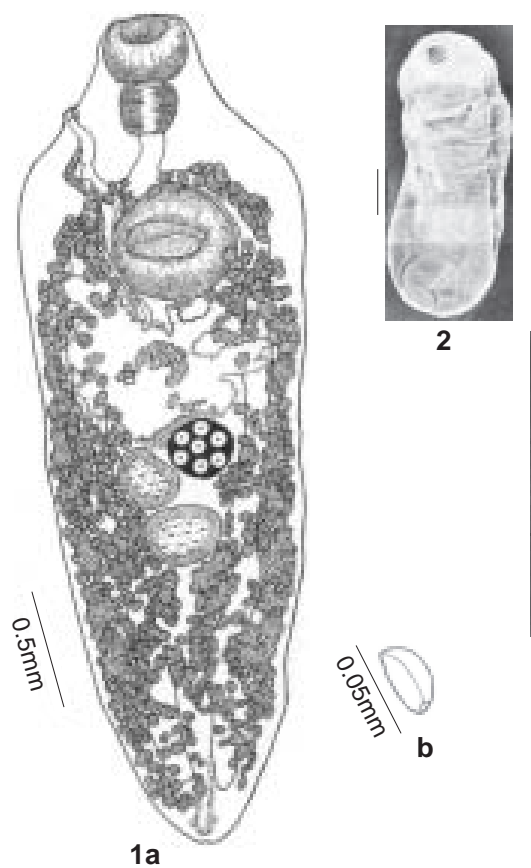

Figures 1-3. Batrachotrema nagalandensis sp. nov. 1a - Whole mount, dorsal view; 1 b - Egg; 2-3 - Scanning electron micrographs: 2 - Full worm, ventral view (scale $100 \mathrm{~mm}$ ); 3 - A magnified view of anterior end, showing the oral end and ventral sucker (scale 100mm).

[See Figures $2 \& 3$ on the web as Images 1 \& 2]

equatorial, located in broader part of body, three times larger than oral sucker, covering half of body in width, strongly muscular. Prepharynx indistinct; pharynx muscular; oesophagus of moderate length or short; intestinal caeca reaching near posterior end. Testes rounded or oval, lying in tandem in middle third of body; anterior testis at level of ovary, slightly smaller than posterior; cirrus sac long, extending posteriorly beyond ventral sucker, lying on its left side, extending anteriorly up to and ending in level with pharynx. Ovary rounded, pretesticular, postacetabular; oviduct, Mehlis' gland complex in region anterior to ovary; uterine coils mainly limited in ovarian and postacetabular area, overlapping intestinal caeca. Genital pore at left side of body, marginal or sub marginal, male and female pores opening into genital atrium. Vitellaria follicular, extending from level of intestinal bifurcation up to posterior most part of body, overlapping intestinal caeca, also scattered in intercaecal fields. Eggs numerous, large, oval. The measurements of this form are given in Table 1.

\section{Discussion}

In having a pretesticular ovary, which is nearer to the anterior testis than the ventral sucker and the genital pore lying laterally to the median line in level with the pharynx, the present form bears a close morphological resemblance to the genus Batrachotrema. Dollfus and Williams (1966) proposed a new family Batrachotrematidae for the genus. Yamaguti (1971) retained the family as proposed by Dollfus and Williams and Wang (1980) also accepted its validity. However, Prudhoe and Bray (1982), on the basis of its close morphological relationship
Table 1. Measurements (in $\mathrm{mm}$ ) of Batrachotrema nagalandensis sp. nov.

\begin{tabular}{|c|c|c|}
\hline Characters & Range (Mean) & \pm S.D. \\
\hline $\begin{array}{l}\text { Length of Body } \\
\text { Maximum width of body (at level of } \\
\text { ventral sucker) }\end{array}$ & $\begin{array}{l}2.38-3.89(2.93) \\
0.80-1.27(1.01)\end{array}$ & $\begin{array}{l}0.49 \\
0.202\end{array}$ \\
\hline $\begin{array}{l}\text { Oral sucker: } \\
\text { Length } \\
\text { Breadth }\end{array}$ & $\begin{array}{l}0.17-0.27(0.21) \\
0.26-0.37(0.33)\end{array}$ & $\begin{array}{l}0.043 \\
0.034\end{array}$ \\
\hline $\begin{array}{l}\text { Ventral Sucker: } \\
\text { Length } \\
\text { Breadth }\end{array}$ & $\begin{array}{l}0.30-0.49(0.42) \\
0.39-0.56(0.47)\end{array}$ & $\begin{array}{l}0.07 \\
0.07\end{array}$ \\
\hline $\begin{array}{l}\text { Pharynx: } \\
\text { Length } \\
\text { Breadth }\end{array}$ & $\begin{array}{l}0.17-0.25(0.22) \\
0.17-0.31(0.20)\end{array}$ & $\begin{array}{l}0.032 \\
0.036\end{array}$ \\
\hline $\begin{array}{l}\text { Length of Oesophagus } \\
\text { Distance of intestinal caeca from hind end } \\
\text { Intestinal bifurcation from anterior end }\end{array}$ & $\begin{array}{l}0.24-0.46(0.41) \\
0.07-0.25(0.22) \\
0.46-0.75(0.64)\end{array}$ & $\begin{array}{l}0.023 \\
0.037 \\
0.01\end{array}$ \\
\hline $\begin{array}{l}\text { Testis I: } \\
\text { Length } \\
\text { Breadth }\end{array}$ & $\begin{array}{l}0.20-0.22(0.22) \\
0.22-0.34(0.27)\end{array}$ & $\begin{array}{l}0.017 \\
0.035\end{array}$ \\
\hline $\begin{array}{l}\text { Testis II: } \\
\text { Length } \\
\text { Breadth }\end{array}$ & $\begin{array}{l}0.24-0.46(0.31) \\
0.19-0.36(0.31)\end{array}$ & $\begin{array}{l}0.077 \\
0.058\end{array}$ \\
\hline $\begin{array}{l}\text { Ovary: } \\
\text { Length } \\
\text { Breadth } \\
\text { Extent of Vitellaria } \\
\text { Eggs }\end{array}$ & $\begin{array}{l}0.22-0.29(0.26) \\
0.19-0.28(0.24) \\
1.89-3.05(2.37) \\
0.03-0.04 \times 0.02-0.023 \\
(0.036 \times 0.022)\end{array}$ & $\begin{array}{l}0.012 \\
0.022 \\
0.419 \\
0.002\end{array}$ \\
\hline
\end{tabular}

with the members of Opecoeliidae, placed the genus under the latter family.

The genus Batrachotrema so far includes five species: $B$. petropedetis Dollfus and Williams, 1966 from Petropedetes natator in Sierra Leone, Africa; B. pseudobagri Wang, 1981 (from Pseudobagrus fulvidraconis and Pseudogastromyzon zebroidus in Fujian Province, China); B. yaanensis Zhang and Sha, 1985 (from Rana phrynoides in Yaan, Sichuan, China); $B$. opistosacca Liang and Ke, 1988 (from Rana spinosa in Meixian, Guangdong, China); B. vietnamensis Moravec and Sey, 1989 (from Rana kuhlii in Hanoi, Vietnam).

A comparison of the present form with the type species reveals several differences between the two. In the present form the testes lie in the middle third of the body and the cirrus sac is long extending posteriorly beyond the ventral sucker. In the type species the testes are located much posteriorly and the claviform cirrus sac is quite small extending posteriorly only up to the anterior margin of the ventral sucker. Both $B$. petropedetis and B. opistosacca have an elongated oval body shape and have intestinal caeca extending posteriad a little beyond the testes. In having a fusiform body, the present species resembles $P$. pseudobagri, a species described from piscine hosts, but distinctly differs from it in having a larger body size, a rounded ovary (lobate in P. pseudobagri), and a long cirrus sac that extends posteriad much beyond the ventral sucker. In possessing an unspined body, testes situated in the middle third of the body and immediately pretesticular ovary that is 
not separated from testes by uterine coils, the present form comes close to B. petropedetis, B. pseudobagri and $B$. opistosacca and stands apart from B. yaanensis and $B$. vietnamensis. In view of the apparent morphological differences and also different amphibian host species the present form is considered a new species under the genus Batrachotrema. It is for the first time that a representative of the genus is being reported from the Indian subcontinent.

Family Batrachotrematidae

Genus Opisthioparorchis Wang, 1980

Opisthioparorchis indica sp. nov.

(Figs. 4-8; Images 3-6w)

\section{Material examined \\ Holotype: W 8341/1; from the intestine of Amolops afghanus (Günther), Mokokchung, Nagaland $\left(25^{\circ}-27^{\circ} 4^{\prime} \mathrm{N} \& 93^{\circ} 2^{\prime}-95^{\circ} 15^{\prime} \mathrm{E}\right)$ Paratypes: W 8342/1, 8343/1; same as holotype. \\ Deposited at the Zoological Survey of India, Kolkata.}

\section{Etymology}

Named after the country.

\section{Specific Diagnosis}

Intestinal caeca extending much beyond ventral sucker up to anterior level of testes, ventral sucker almost equal to oral sucker in size, genital pore in level with anterior margin of oral sucker, vitellaria extending beyond testes posteriorly, confluent medially in pre-and posttesticular regions.

\section{Diagnosis}

(Based on measurements of 10 mature flukes and SEM observations on 2 specimens.). Body elongate or oval with rounded anterior end, rounded or slightly conical posterior end, spinose. Oral sucker subterminal, spherical. Ventral sucker pre-equatorial or equatorial almost equal to oral sucker in size. Prepharynx indistinct; pharynx muscular; oesophagus of moderate length; intestinal caeca extending in postacetabular region up to level of anterior margin of testes. Testes round or oval, lying symmetrically juxtaposed in posterior region of body; cirrus sac well developed, elongated, somewhat Sshaped, recurved, lying on left side of body, extending from near junction of oesophagus and intestinal caeca up to anterior margin of oral sucker. Ovary rounded, pretesticular, postacetabular; receptaculum seminis conspicuous, lying posterior to ovary; uterus pretesticular, occupying major area between ovary and testes, extending anteriad partially overlapping intestinal caeca. Genital pore marginal on left at level of anterior margin of oral sucker. Vitellaria in varying follicular size, extending in lateral fields from level of pharynx posteriorly up to post-testicular region, becoming confluent medially in intercaecal, pretesticular and post testicular fields. Eggs numerous, ovoid, operculate.

SEM revealed the surface fine topography of the fluke. The body surface is studded throughout with dense spination except for the anterior circum-oral region, which appears devoid of spines. Whereas the spines covering the tegument in most

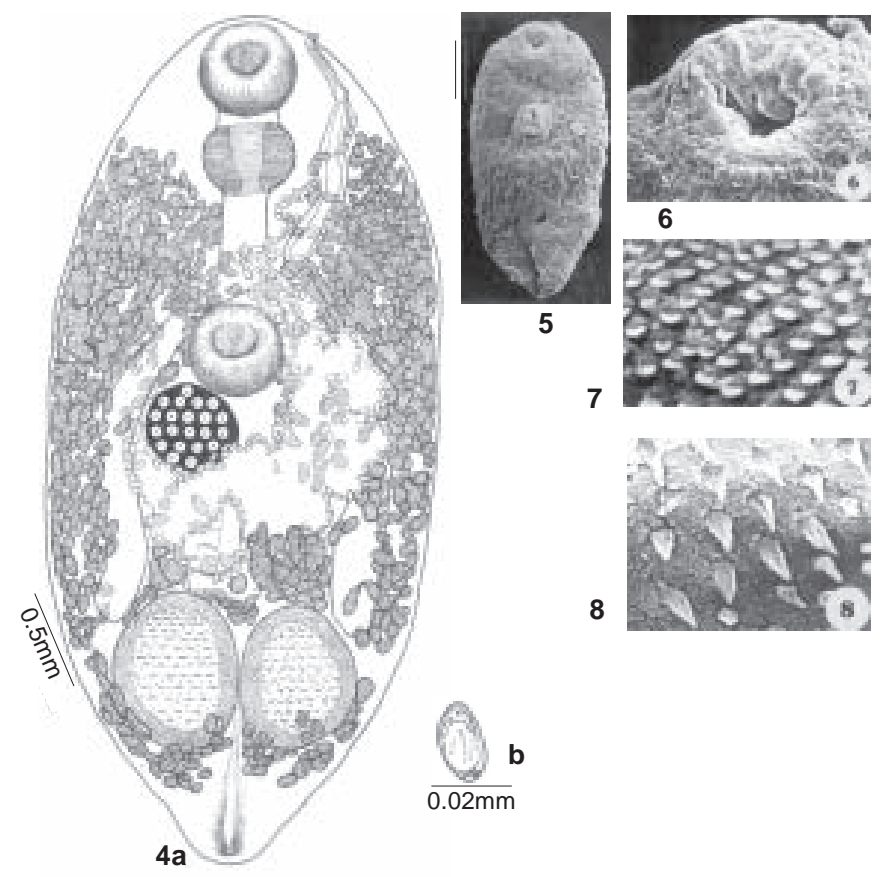

Figures 4-8. Opisthioparorchis indica sp. nov. 4a. Whole mount, ventral view, b. Egg; 5-8. Scanning electron micrographs: 5 - Whole worm, ventral view (scale $100 \mathrm{~mm}$ ); 6 - Oral end, magnified view (scale 10mm); 7 - A magnified view of the tegumental spination in the mid ventral region (scale 10mm); 8 - Tegument of the posterior part of the body depicting conical spines (scale 10mm) [See Figures 5-8 on the web as Images 3-6]

parts of the body are scale like with rounded tips, those abounding in the posterior region are conical, with broad base and pointedly tapering distal end. The non-spinous tegument of the anterior region presents a spongy texture. The measurements of this form are given in Table II.

\section{Discussion}

In having a well-developed cirrus sac and marginal or submarginal genital pore located in the region of the oral sucker or pharynx, the present form belongs to the family Batrachotrematidae.

The genus Opisthioparorchis was created by Wang (1980) for an intestinal fluke of Rana spinosa, which was characterized by having juxtaposed testes located at the posterior end of the body and intestinal caeca extending up to just near the anterior border of testes. At present the genus includes six species, all described from China: O. ranae Wang, 1980 (type species) from Rana spinosa in Fujian Province South; O. pleurogenitus Wang, 1980 from the same host and locality as those of the type species; O. boheansis Wang, 1980 from Staurois wuyiensis also from Fujian; O. megaloonis Liang and Ke, 1988 and $O$. meixianensis Liang and Ke, 1988, both from $R$. spinosa in Changsha (Meixian, Guangdong Province) and O. yunnanse Li, 1996 also from $R$. spinosa from Yunnan Province.

In having the vitellaria extending in the posttesticular region, 
Table 2. Measurements (in $\mathrm{mm}$ ) of Opisthioparorchis indica sp. nov.

\begin{tabular}{|c|c|c|}
\hline Characters & Range (Mean) & \pm S.D. \\
\hline $\begin{array}{l}\text { Length of Body } \\
\text { Maximum width of body (at level of } \\
\text { ventral sucker) }\end{array}$ & $\begin{array}{l}1.80-2.33(2.05) \\
0.89-1.08(0.97)\end{array}$ & $\begin{array}{l}0.18 \\
0.08\end{array}$ \\
\hline $\begin{array}{l}\text { Oral sucker: } \\
\text { Length } \\
\text { Breadth }\end{array}$ & $\begin{array}{l}0.21-0.26(0.24) \\
0.23-0.30(0.26)\end{array}$ & $\begin{array}{l}0.02 \\
0.026\end{array}$ \\
\hline $\begin{array}{l}\text { Ventral Sucker: } \\
\text { Length } \\
\text { Breadth }\end{array}$ & $\begin{array}{l}0.21-0.25(0.23) \\
0.21-0.27(0.24)\end{array}$ & $\begin{array}{l}0.014 \\
0.018\end{array}$ \\
\hline $\begin{array}{l}\text { Pharynx: } \\
\text { Length } \\
\text { Breadth }\end{array}$ & $\begin{array}{l}0.19-0.23(0.21) \\
0.2-0.24(0.22)\end{array}$ & $\begin{array}{l}0.018 \\
0.016\end{array}$ \\
\hline $\begin{array}{l}\text { Length of Oesophagus } \\
\text { Distance of intestinal caeca from hind end } \\
\text { Intestinal bifurcation from anterior end }\end{array}$ & $\begin{array}{l}0.14-0.23(0.18) \\
0.58-0.77(0.68) \\
0.53-0.65(0.61)\end{array}$ & $\begin{array}{l}0.03 \\
0.06 \\
0.04\end{array}$ \\
\hline $\begin{array}{l}\text { Testis (right): } \\
\text { Length } \\
\text { Breadth }\end{array}$ & $\begin{array}{l}0.33-0.46(0.39) \\
0.26-0.33(0.29)\end{array}$ & $\begin{array}{l}0.04 \\
0.023\end{array}$ \\
\hline $\begin{array}{l}\text { Testis (left): } \\
\text { Length } \\
\text { Breadth } \\
\text { Cirrus sac Length }\end{array}$ & $\begin{array}{l}0.33-0.41(0.38) \\
0.25-0.32(0.28) \\
0.52-0.66(0.57)\end{array}$ & $\begin{array}{l}0.03 \\
0.029 \\
0.05\end{array}$ \\
\hline $\begin{array}{l}\text { Ovary: } \\
\text { Length } \\
\text { Breadth }\end{array}$ & $\begin{array}{l}0.17-0.25(0.22) \\
0.17-0.23(0.20)\end{array}$ & $\begin{array}{l}0.027 \\
0.022\end{array}$ \\
\hline $\begin{array}{l}\text { Receptaculum seminis: } \\
\text { Length } \\
\text { Breadth }\end{array}$ & $\begin{array}{l}0.36-0.53(0.44) \\
0.03-0.065(0.047)\end{array}$ & $\begin{array}{l}0.07 \\
0.013\end{array}$ \\
\hline Eggs & $\begin{array}{l}0.027-0.037 \times 0.011- \\
0.018(0.031 \times 0.015)\end{array}$ & 0.002 \\
\hline
\end{tabular}

the present form resembles the type and other species but stands apart from $O$. pleurogenitus and $O$. yunnanse, in both of which the vitelline follicles are distributed only in the pretesticular region and the testes are the posterior most structures in location in the fluke body. It also differs from all those species having posttesticular vitellaria in several characters; the latter species, have a much smaller body size, the ventral sucker is smaller than the oral and unlike the present form, the vitellaria do not become confluent medially in the pretesticular, inter-intestinal and posttesticular regions.

In view of the conspicuous differences of the present form with the hitherto known species of Opisthioparorchis, it is proposed to consider this as a new species named $O$. indica.

\section{Opisthioparorchis yunnanse Li, 1996} (Fig. 9)

\section{Material examined}

From the intestine of Rana liebigii (Günther), Kohima (Nagaland, $25^{0}-27^{0} 4^{\prime} \mathrm{N}$, India).

\section{Diagnosis}

(Whole mount). Body elongate, somewhat narrow anteriorly, broader posteriorly, with bluntly rounded ends, spinose. Oral sucker subterminal, almost twice as large as ventral sucker,

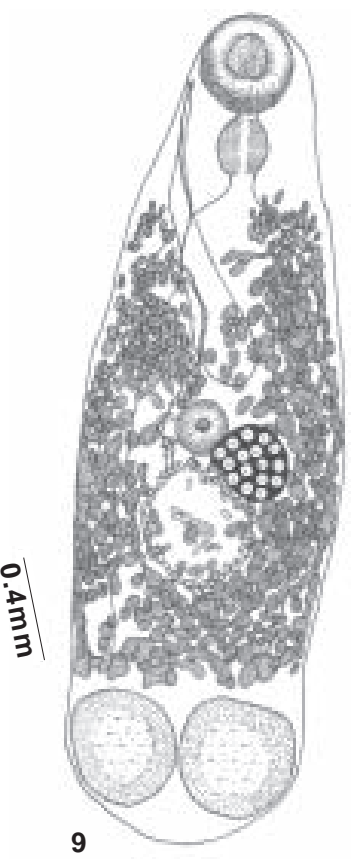

Figure 9. Opisthioparorchis yunnanse Li, 1996 Whole mount, ventral view

Table 3. Measurements (in $\mathrm{mm}$ ) of Opisthioparorchis yunnanse

\begin{tabular}{ll}
\hline Characters & Measurement \\
\hline Length of Body & 2.5 \\
Maximum width of body (at level of ventral sucker) & 1.94 \\
Oral sucker: & \\
Length & 0.28 \\
Breadth & 0.29 \\
Ventral Sucker: & \\
Length & 0.08 \\
Breadth & 0.08 \\
Pharynx: & \\
Length & 0.18 \\
Breadth & 0.20 \\
Length of Oesophagus & 0.09 \\
Distance of intestinal caeca from hind end & 0.58 \\
Intestinal bifurcation from anterior end & 0.6 \\
Testis (right): & \\
Length & \\
Breadth & 0.37 \\
Testis (left): & 0.35 \\
Length & \\
Breadth & \\
Cirrus sac Length & 0.38 \\
Ovary: & 0.31 \\
Length & 0.97 \\
Breadth & \\
Receptaculum seminis:LengthBreadth & 0.23 \\
Eggs & 0.23 \\
& 0.420 .047 \\
& \\
& \\
& \\
&
\end{tabular}

latter equatorial in position. Prepharynx short, pharynx muscular; oesophagus short; intestinal caeca extending posterial up to a little in front of testes. Testes round or oval, juxtaposed near posterior extremity of body; cirrus sac clubshaped, elongated, extending from a little in front of ventral 
sucker anteriad up to level of oral sucker. Ovary rounded, just by side or slightly posterior to ventral sucker; uterus mainly in near post ovarian region, extending as ascending narrow tube anteriad. Genital pore marginal, on left at level of oral sucker. Vitellaria extending extensively from level of oesophagus posteriad up to just in front of testes. Eggs elliptical, operculate. The measurements of this form are given in Table III.

\section{REMARKS}

The whole mount preparation of one specimen collected from Rana liebigii, though apparently resembled Opisthioparorchis species, turned out to be different from the new species of the genus described above. In its general morphology (elongated body, oral sucker larger than the ventral sucker- almost double the size, vitellaria limited to only pretesticular zone and long club-shaped cirrus sac), the present specimens stands close to O. yunnanse Li, 1996, which was originally described from Rana spinosa from Yunnan Province, China. However, the only conspicuous deviation it shows from this species is the length of the oesophagus; in $O$. yunnanse the oesophagus is quite long, though short in the present form. However, considering that just one character i.e. length of the oesophagus, is not enough to erect a new species, the present form is considered representing $O$. yunnanse.

\section{REFERENCES}

Dollfus, R.P.F. and M.O. Williams (1966). Recherches de affinités naturelles d'un distome parasite de Batracien anoure de Sierra-Leone. Bulletin du Muséum national d'Histoire naturelle de Paris, 2 série 38: 201-207.

Li, D.-N. (1996). Two new species of trematode of frogs in Yunnan Province. Annual Bulletin of the Society of Parasitology, Guangdong Province 18: 60-63.

Liang, C. and X.I. Ke (1988). Four new trematodes of mammals and amphibians from Guangdong Province. Annual Bulletin of the society of Parasitology Guangdong Province 10: 129-133.

Moravec, F. and O. Sey (1989). Some amphibian trematodes from Vietnam and Papua New Guinea. Vist. Cs. Spolec. Zool. 53: 265-279.

Prudhoe, S. and R.A. Bray (1982). Platyhelminth Parasites of the Amphibia. British Museum (Natural History) and Oxford University Press, London.

Roy, B. and V. Tandon (1991). Usefulness of tetramethylsilane in the preparation of helminth parasites for scanning electron microscopy. Rivista di Parasitologia 8: 207-215.

Wang P.-Q. (1980). [Report on some trematodes from amphibians and reptiles in Fujian, South China]. Fujian Shida Xuebao [Journal of Fujian Normal University] 1: 81-92.

Wang, P.-Q. (1981). [Notes on some trematodes from freshwater fishes in Fujian Province]. Fujian Shida Xuebao [Journal of Fujian Normal University] 2: $81-90$

Yamaguti, S. (1971). Synopsis of digenetic trematodes of vertebrates. Vol. I. Keigaku Publishing Co., Tokyo.

Zhangs, T.-F. and G.-R. Sha (1985). [Two new species of trematodes from frogs in Sichuan Province (Trematoda: Batrachotrematidae, Omphalometridae)]. Acta Zootaxonomica Sinica 10: 350-353.

\footnotetext{
ACKNOWLEDGEMENTS

A part of this study was carried out under the 'All India Coordinated Project on Capacity Building in Taxonomy: Research on Helminths', sanctioned to VT at NEHU as a collaborating centre by Ministry of Environment \& Forests, GOI The authors are grateful to the Head, Department of Zoology and the Head, Regional Sophisticated Instrumentation Center, NEHU, for providing laboratory and Scanning Electron Microscopy facilities, respectively. We thank the Coordinator, Bioinformatics Centre, NEHU for allowing access.
}

\section{ANT DIVERSITY IN SOME SELECTED LOCALITIES OF SATTUR TALUK, VIRUDHUNAGAR DISTRICT, TAMIL NADU}

\author{
T. Rajagopal ${ }^{1}$, S.P. Sevarkodiyone ${ }^{2}$ and \\ A. Manimozhi ${ }^{3}$
}

1, 2 Post-Graduate and Research Department of Zoology, Ayya Nadar Janaki Ammal College (Autonomous), Sivakasi, Tamil Nadu 626124, India;

${ }^{3}$ Arignar Anna Zoological Park, Vandalur, Chennai, Tamil Nadu 600 048, India

Email: ${ }^{1}$ deer_raj@yahoo.co.in.

Social insects in general, and ants in particular have achieved unprecedented ecological success and dominance in tropical ecosystem (Gadagkar et al., 1993). Social way of life adapted by all ant species brings with it both benefits and cost (Brain, 1975). Being such dominant and successful component of ecosystems, it is likely that ants would turn out to be good indicators of the well being of the ecosystem (Daniels, 1991). However, a literature survey revealed that only limited studies are available on diversity of ants. This may be due to lack of appropriate methodologies of tropical insect communities, especially ants (Gadagkar et al., 1990). The present study was carried out in an attempt to understand and measure the status of ant species diversity in some selected localities of Sattur taluk $\left(9^{0} 10^{\prime} \mathrm{N} \& 77^{0} 52^{\prime} \mathrm{E}\right.$; $\left.61.19 \mathrm{~m}\right)$, Virudhunagar district, Tamil $\mathrm{Nadu}$, in riverine, cultivated and industrial areas.

The study was carried out for seven months from August 2001 to February 2002. The ants were collected from three selected localities: cultivated areas (paddy, cotton, brinjal, ladies finger, Cassia fistula, banana, coconut, guava, palm etc), riverine areas (vegetation found along the banks of Arjuna and Vaiparu rivers), and industrial areas (match factories, fire works and printing industries). The average rainfall during the period was $75.84 \mathrm{~mm}$ in Sattur taluk. Maximum and minimum temperatures were $35^{\circ} \mathrm{C}$ and $26^{\circ} \mathrm{C}$, respectively. All the collected specimens were preserved in $70 \%$ alcohol. Ants were separated and sent to the Center for Ecological Science at Indian Institute of Science, Bangalore for identification and confirmation of ant specimens, with the help of Dr. R. Gadagkar, Director, CES. Relative abundance of ant species were calculated using the following formula (Micheal, 1986).

Relative abundance $=\frac{\text { Total number of individuals of the species }}{\text { Total number of individuals of all species }} \times 100$

A total of 25 species of ants belonging to 14 genera distributed in six subfamilies were recorded (Table 1). The subfamilies included Formicinae ( 9 species) followed by Myrmicinae ( 8 species), Pseudomyrmicinae (4 species), Ponerinae (2 species), Dorylinae / Dolichoderinae (1 species). The study revealed that more number of ant species were recorded in the riverine (24 species) and cultivated areas (20 species).

(C) Zoo Outreach Organisation; www.zoosprint.org Manuscript 1091: Received 17 September 2003: Revised received 03 February 2005; Finally accepted 10 April 2005; Date of publication 21 May 2005 